\title{
Inter- and Intraspecific Variability in Invertebrate Acute Toxicity Response to Arsenic and Fluoride Exposure
}

\author{
López-Gutiérrez, Luis-Fernandoㅁ, Rubio-Franchini, Isidoro ${ }^{2}$, Rico-Martínez, Ro- \\ berto $^{1^{*}}$, Mesquita-Joanes, Francesc ${ }^{3}$, Ramírez-López, Elsa Marcela ${ }^{1}$, Arredon- \\ do-Figueroa, José Luis ${ }^{1}$ and Silva-Briano, Marcelo ${ }^{1}$
}

\begin{abstract}
:
The adverse effects of arsenic and fluoride exposure on six groups of freshwater invertebrates were investigated. Acute toxicity tests $(48-\mathrm{h})$ with arsenic trioxide $\left(\mathrm{As}_{2} \mathrm{NO}_{3}\right)$ resulted in the following pattern of sensitivity: Daphnia magna 24-h-old = Brachionus patulus 72-h-old = Daphnia. cf. prolata, 21-d-old = D. magna 5-d-old > Heterocypris incongruens juvenile instars > Culex sp. Heterocypris juv. incongruens instars were the second group more tolerant to arsenic and the second group that bioconcentrates arsenic the least. In contrast, invertebrates exposed to sodium fluoride $(\mathrm{NaF})$, showed a different pattern of sensitivity: H. incongruens instars $>$ B. patulus $=$ D. magna 24 -h-old $>$ D. cf. prolata 21 -d-old $=$ Culex $\mathrm{sp} .=D$. magna 5 -d-old. Our results suggest that all species tested might be considered good model tests organisms for As toxicity except $H$. incongruens. The rotifer $B$. patulus did not accumulate either arsenic or fluoride; and its sensitivity was intermediate for both toxicants. In contrast, $D$. cf. prolata accumulated more fluoride and was also (together with 5-d-old D. magna) the most tolerant to fluorine. In the case of arsenic, 5-d-old D. magna were the organisms with highest accumulation rates, but their sensitivity was similar to all other species (except for Culex sp. and H. incongruens). Interestingly, H. incongruens juv. instars have low sensitivity to As but are the most sensitive species to fluoride exposure. These results point out to the need of consider several invertebrate species as model organisms for environmental protection of particular ecosystems, or that some freshwater species have the potential to be used as fluorine bioaccumulators in remediation processes.
\end{abstract}

\section{Introduction}

Over the last two decades various methods have been developed to evaluate sediment toxicity, ranging from small-scale, short-term lethality tests to larger-scale, longer-term, chronic tests, measuring contaminants effects on single sentinel species, e.g. the ostracod Heterocypris incongruens (Havel \& Talbott, 1995; Chial and Persoone, 2003; Oleszczuk 2007), cladocerans (Camargo, 2002), mosquitoes like Culex spp. larvae and rotifers (Alvarado-Flores et al., 2012).

An effective biological monitoring program needs sentinel organisms carefully selected that allow evaluation of pollutants and their bioavailability in a wide assemblage of test organisms (Aguilar-Alberola and Mesquita-Joanes, 2012). However, not all biotic factors or abiotic processes are fully understood. Moreover, the relationship between chemical form, bioconcentration, temperature, hardness and dissolved oxygen, among
${ }^{1}$ Universidad Autónoma de Aguascalientes, Centro de Ciencias Básicas, Departamento de Química, Laboratorio de toxicología acuática, Avenida Universidad, Aguascalientes, Ags., México

2 Laboratorio Estatal de Salud Pública, Insituto de Salud del Estado de Aguascalientes, Av. Siglo XXI \#105 Ciudad Satélite Morelos Aguascalientes, Aguascalientes México.

${ }^{3}$ Cavanilles Institute of Biodiversity and Evolutionary Biology, Universitat de Valencia, Valencia, Spain

*Corresponding author: Dr. Roberto, Rico-Martinez, Universidad Autónoma de Aguascalientes, Centro de Ciencias Básicas, Departamento de Química, Laboratorio de toxicología acuática, Avenida Universidad, Aguascalientes, Ags., México, C.P. 20131; E-mail: rrico@correo.uaa.mx

Received date: August 24, 2017 Accepted date: January 30, 2018 Published date: February 6, 2018

Citation: López-Gutiérrez et al. Interand Intraspecific Variability in Invertebrate Acute Toxicity Response to Arsenic and Fluoride Exposure. (2018) J Environ Health Sci 4(1): 1-7.

Keywords: $\mathrm{LC}_{50}$; Zooplankton; Water flea; Seed shrimp; Bioindicator; Self-protection 
Citation: López-Gutiérrez, et al. Inter- and Intraspecific Variability in Invertebrate Acute Toxicity Response to Arsenic and Fluoride Exposure. (2018) J Environ Health Sci 4(1): 1-10.

other factors, will determinate the adaptive self-protection mechanisms of organisms, thereby influencing toxicological sensitivity, tolerance or resistance (Puig and Sanz, 1987; Philips 1990; Forget et al., 1998; Canivet et al., 2001; Ambasht and Ambasht 2003; Aguilar-Alberola and Mesquita-Joanes, 2012).

Arsenic can be found naturally in the environment and is classified as a metalloid (ASTDR, 2007); $\mathrm{As}_{2} \mathrm{O}_{3}$ has been widely used in pesticides, paints, glass, alloys, medicines, preservative on wood, etc. (Philips, 1990). Now a days, about $90 \%$ of all arsenic being produced is used as a preservative for wood which is called copper chromated arsenate (CCA). In 2003, U.S. manufacturers of wood preservatives containing arsenic began transition from CCA to other wood preservatives without arsenic in wood products (ASTDR, 2007).

Fluor (F) is a lighter element from group VII, the halogens family; it forms inorganic and organic substances called fluorides that can be toxic for living systems (Yu, 2000). Alive organisms are exposed mainly through food and water. Fluorides represent approximately $0.06-0.09 \%$ of the land (Mitchell et al., 2011). Intoxication by fluorides has been estimated in oral doses of at least $1000 \mu \mathrm{g} \mathrm{ml}^{-1}$ (World Health Organization, 2006); in fact, calcium and sodium fluorides can be present in water with concentrations around $30,000 \mu \mathrm{g} \mathrm{ml}^{-1}$; most of the fluorides and arsenic components have little bioavailability due to salt complexation; but acid rain release these compounds to the environment (Philips 1990; Bailey et al., 2006; Jaramillo et al., 2009). Fluoride concentrations in unpolluted freshwaters range from 10 to $300 \mu \mathrm{g} \mathrm{ml}^{-1}$, while in unpolluted seawaters they generally range from 1200 to $1500 \mu \mathrm{g} \mathrm{ml}^{-1}$ (Camargo, 2002). The goal of this work was to analyze the lethal effects and bioconcentration of arsenic and sodium fluoride on six freshwater invertebrates: a) ostracod $H$. incongruens instars $\mathrm{A} 8 / \mathrm{I}$ and A7/II, b) cladocerans D. cf. prolata 21-d-old, c) D. magna $<24$-h-old or 5-d-old d) mosquito larvae Culex sp., instar IV and e) rotifer B. patulus adults $>72$-h-old.

\section{Materials and Methods}

\section{Collection of organisms}

All organisms were collected in Aguascalientes State, Mexico, with a $120-\mu \mathrm{m}-\mathrm{mesh}-\mathrm{size}$ zooplankton net. The ostracod $H$. incongruens was collected in La Punta pond (geographic coordinates: $21^{\circ} 51^{\prime} 54^{\prime \prime} \mathrm{N}, 102^{\circ} 18^{\prime} 57.5^{\prime \prime} \mathrm{W}$ ), the rotifer B. patulus was collected at the Chichimeco reservoir $\left(21^{\circ} 53^{\prime} 41^{\prime \prime} \mathrm{N}, 102^{\circ} 51^{\prime} 02^{\prime \prime} \mathrm{W}\right)$, D. cf. prolata in Jocoqui reservoir, $\left(22^{\circ} 08^{\prime} \mathrm{N}, 102^{\circ} 20^{\prime} \mathrm{W}\right)$, the mosquito larvae Culex sp., were collected at a pond at the Universidad Autónoma de Aguascalientes (UAA), $\left(21^{\circ} 52^{\prime} \mathrm{N}, 102^{\circ} 43^{\prime} \mathrm{W}\right)$. D. magna has been cultured at the laboratory of environmental toxicology of UAA for over fifteen years.

\section{Acute Toxicity Tests}

The age of the individuals of the different species were selected in accordance to preliminary experiments where the most sensitive stages were selected. These correspond to: a) $H$. incongruens (24-48 h), b) Daphnia magna (24-h and 5-days), c) B. patulus (72-h), e) D. cf. prolata (21-days), and mosquito larvae Culex sp. (instar IV). Fifty adult organisms of each species were placed in glass Petri dishes or polyurethane jars, to start a culture in EPA medium, prepared adding to 1 liter of deionized water: $96 \mathrm{mg}$ of $\mathrm{NaHCO}_{3}, 60 \mathrm{mg} \mathrm{CaSO} \mathrm{m}_{4} \cdot 2 \mathrm{H}_{2} \mathrm{O}, 60 \mathrm{mg}$ of $\mathrm{MgSO}_{4}$ $-7 \mathrm{H}_{2} 0$, and $4 \mathrm{mg}$ of $\mathrm{KCl}$. This medium has moderately hard water (80-100 mg $\left.\mathrm{CaCO}_{3} \mathrm{l}^{-1}, \mathrm{pH} 7.5\right)$. The organisms were maintained in two bioclimatic chambers (Revco Scientific, Asheville, $\mathrm{NC}$, USA), ostracods and rotifers were grown at a temperature of $25 \pm 2{ }^{\circ} \mathrm{C}$, cladocerans and insects at $20 \pm 2^{\circ} \mathrm{C}$, this endpoint were monitored by microcomputer thermometer (Hanna Instruments, Woonsocket, RI, USA) and photoperiod of 16:8 h of light: darkness. Light intensity was 400-1000 luxes or 18.04 $\mu \mathrm{E} / \mathrm{s} \bullet \mathrm{m}^{2}$ using cold light lamps, determined with a luminometer (Kyoritsu Electrical Instruments, Tokyo, Japan). Deionized water was obtained from a Water Pro System (Labconco Co., Kansas City, USA) at $18 \mathrm{M} \Omega$. Ostracods, cladocerans and insects were fed with the green algae Pseudokirchneriella subcapitata, rotifers fed with Nannochloris oculata $<15$ days old grown in Bold's Basal Medium (Nichols, 1973). The origin of this strain was the Texas University Algal Collection (UTEX, collection LB2194), all species at this moment were reproduced with algae provided ad libitum. Then, invertebrates were placed in a jar (sterile polyurethane) and for ostracods we added a wooden stick of dehydrated bark (corm) of an Agavaceae plant, $2.5 \mathrm{~mm}$ length, where parthenogenic females could lay their eggs. Dead animals were replaced for living ones picked up from the stock culture. The offspring of these animals were used to carry out the acute toxicity tests. Species identification was performed using the taxonomic keys of Koste (1978), Meisch (2000), and Hevert (2002).

To start the 48-h acute toxicity tests we used the following specimens: $H$. incongruens offspring instars A-8/I (females $<24$-h-old, average length $=250 \pm 12.9 \mu \mathrm{m}, \mathrm{N}=50$ individuals) and A-7/II (females < 48-h-old, average length $=344 \pm$ $15.5 \mu \mathrm{m}, \mathrm{N}=50$ ), B. patulus (females 72-h-old, average length $=200 \pm 17.1 \mu \mathrm{m}, \mathrm{N}=50$ ) and $D$. cf. prolata (females 21 -d-old, avg. length $=1738 \pm 154.2 \mu \mathrm{m} \mathrm{N}=60$ ), D. magna (females 24-h-old average length $=1173 \pm 94.9 \mu \mathrm{m}, \mathrm{N}=64$ ) and D. mag$n a$ (females 5-d-old average length $=2434 \pm 339.6 \mu \mathrm{m}, \mathrm{N}=62$ ), mosquito larvae Culex $\mathrm{sp}$. (average length $=6.4 \mathrm{~mm} \pm 0.72 \mathrm{~mm}$, instar IV $\mathrm{N}=30$ ). The toxicants evaluated were reference chemicals of the highest purity available [atomic absorption standards of As dissolved in $1 \% \mathrm{HNO}_{3}\left(\mathrm{As}_{2} \mathrm{O}_{3}\right)$, Sigma Co., Saint Louis $\mathrm{MO}$, USA]. The toxic stocks were prepared in EPA medium. Range finding tests were performed for each invertebrate and each toxicant. The test concentrations ranged from 0.17 to 4.5 $\mathrm{mg} \cdot \mathrm{l}^{-1}$ for $\mathrm{As}_{2} \mathrm{O}_{3}$ and 15 to $1250 \mathrm{mg} \cdot \mathrm{l}^{-1}$, for $\mathrm{NaF}$ (Reactivos Golden Bell®, Mexico).

At the start of the experiment ten female animals with three, six or nine replicates (the number of replicates varied among species because of the differences in the dispersion of the data; $\mathrm{n}=3$ for most species, $\mathrm{n}=6$, for $B$. patulus; $\mathrm{n}=9$ for $H$. incongruens), were placed with an Edmonson pipette in each well of a sterile 24-well polystyrene plates, maximum volume $3 \mathrm{ml}$ (Corning Co., USA, Corning NY, USA) used once for ostracods and rotifers, and jars of $300 \mathrm{ml}$ of polyurethane for cladocerans and mosquito larvae, adding first EPA medium, the invertebrates, and finally the toxic volume corresponding for a final volume of $1000 \mu \mathrm{l} /$ well or $25 \mathrm{ml} / \mathrm{jar}$. The plates or jars were placed in a bioclimatic chamber, under the same conditions previously detailed. Mortality data were recorded at 48-h exposure to determine the median lethal concentration $\left(\mathrm{LC}_{50}\right)$. At the end of lethal test, organisms were counted. Three arsenic and sodium 
fluoride concentrations (one low, one intermediate, and one high with three replicates; $\mathrm{n}=9$ for each toxicant) were determined to calculate the real concentrations for the $\mathrm{LC}_{50}$ values using the protocols for atomic absorption for As and fluoride selection ion for $\mathrm{F}$ according to protocols described below.

\section{Determination of Arsenic Using Atomic Absorption}

Determination of As in water was performed using atomic absorption with a PE A Analyst 800 Spectrometer with (a) transversely heated graphite furnace, (b) longitudinal Zeeman-effect background correction, and (c) AS-60 auto-sampler. The detection limit for As was $0.2 \mu \mathrm{gl}^{-1}$. EPA medium (Weber, 1993) was prepared with deionized water obtained through a Water Pro PS system (Labconco, USA). In water and elutriates for the determination of As, we followed the protocol of the Mexican Norm for metals in water (Secretaría de Salud y Asistencia, 1994). The dry weight of the most abundant species was determined by counting 20,50 or 100 organisms of each species in an Eppendorf tube with a total volume of $1 \mathrm{ml}(\mathrm{n}=5)$, and then drying this volume and obtaining the dry weight according to standard methods (APHA 2005). Organisms were isolated under a dissection microscope and separated from the experiments then washed in deionized water and preserved and fixed with 5 $\%$ instra $\mathrm{HNO}_{3}$. Zooplankton samples were digested in the same way as the water column samples and then analyzed by atomic absorption spectrophotometry in the graphite oven following the Mexican Norm for As in water (Secretaría de Salud y Asistencia, 1994). Bioconcentration Factors (BCFs) were calculated by dividing the mean value of the total As content for a species by the concentration of the surrounding medium (liquid medium used in the respective experiment) as suggested by Paquin et al. (2003).

\section{Determination of Fluorides using a Fluoride Ion Selective Electrode}

Fluoride levels were determined using a 4-Star pH/ISE meter and a Thermo Scientific Orion fluoride selective electrode. We follow the User Guide methodology to determine fluoride levels. The limit of detection of this technique is $0.02 \mathrm{mgl}^{-1}$ of fluoride.

\section{Statistical Analysis}

Mortality data were analyzed with $\mathrm{DL}_{50}$, French software (S.B.I.-I.R.C.T. Montpellier, 1987), which estimates the $\mathrm{LC}_{50}$ values with probit analysis and transforms concentration exposure to logarithmic scale. These data were tested with oneway analysis ANOVA and linear regression analysis, to calculate the significance $(\alpha=0.05)$ and 95\% confidence limits, and endpoint correlation $\left(\mathrm{r}^{2}\right)$ values, with Statistica 7.0 (Statsoft Inc., 2004, Tulsa, OK, USA). Duncan's tests $(\alpha=0.05)$ were used to determine the NOEC's (No Observed Effect Concentration) and LOEC's (Lowest Observed Effect Concentration).

\section{Results and Discussion}

Atomic absorption analysis of As concentration showed a $92.52 \%$ correspondence $(\mathrm{SD}=12.43, \mathrm{n}=9$ ) between the real and the nominal concentrations. A similar analysis of $\mathrm{F}$ concentration with the fluoride selective ion showed a $91.68 \%$ correspondence $(\mathrm{SD}=14.24, \mathrm{n}=9)$. These percentages were used to adjust the $\mathrm{LC}_{50}$ values.

\section{Arsenic}

Juvenile instars (A-7/A-8) of $H$. incongruens were more sensitive to As than Culex sp. However, they are less sensitive when compared with all other remaining groups (Table 1). When the As burden was determined, $H$. incongruens showed the lowest bioconcentration, together with B. patulus (Figure 1). $D$. cf. prolata bioconcentrated As more than fifty-fold. However, the biggest bioconcentrator was D. magna 5-d old with 187.45 $\mathrm{ng} \mathrm{mg}^{-1}$ and the smallest was B. patulus with $0.094 \mathrm{ng} \mathrm{mg}^{-1}$ (Figure 1). The ostracod Heterocypris incongruens, neonates A-8/I and and juveniles A-7/II were less sensitive to As than cladocerans neonates $<24$-h-old, juveniles, or 5-d-old adults, or adult rotifers $>72$-h-old. The ranges of NOEC values $\left(0.2\right.$ to $2.5 \mu \mathrm{g} \mathrm{ml}^{-}$ $\left.{ }^{1}\right)$ and LOEC values ( 0.4 to $\left.3.5 \mu \mathrm{g} \mathrm{ml}^{-1}\right)$ are narrow and suggest that toxicity values for As were in a small range for all species. The highest arsenic value bioconcentrated in this ostracod was $9.5 \mathrm{ng} \mathrm{mg}^{-1}$ (Figure 1). Pastorinho et al. (2009) warn of the risks when evaluation of toxic effects is carried out on adults only; they showed that smaller instars, neonates and juveniles, of the amphipod Echinogammarus marinus may bioaccumulate higher amounts of $\mathrm{Cd}$ and $\mathrm{Zn}$ than adults after 96-h of exposure to a concentration of $1 \mu \mathrm{g} \mathrm{ml}^{-1}$. Taylor et al. (1977) also determined age differences of toxicological sensitivity in instars of crab Carcinus maenas. At 96- $\mathrm{h}$ exposure to $\mathrm{Ag}$, the $\mathrm{LC}_{50}$ for adults was $1 \mu \mathrm{g} \mathrm{ml}^{-1}$, while it was only $0.1 \mu \mathrm{g} \mathrm{ml}^{-1}$ for the young Zoe II. Barka et al. (2001), working with the marine copepod Tigriopus japonicus, found that neonates were ten-fold more sensitive than adults. The crab Jasus berreauxxi from Australia concentrated 60-272 $\mu \mathrm{g} \cdot \mathrm{g}^{-1}$ (Philips, 1990). We reported bioconcentrations for 5-d-old D. magna, ranging from 88 to $253 \mathrm{ng} \mathrm{mg}^{-1}$ (Figure 1). The rotifer $B$. patulus was the species that bioconcentrated less arsenic (Figure 1). Havel and Talbott (1995) found significant statistical differences between four localities using as sentinels H. incongruens and Ceriodaphnia dubia exposed to sediments from stream sites contaminated with metals $\mathrm{Cd}, \mathrm{Cu}, \mathrm{Pb}, \mathrm{Ni}$ and $\mathrm{Zn}$. They considered as endpoints, the survival and fertility for $C$. dubia, and for $H$. incongruens body length or survival, and the ostracods were more sensitive than the cladocerans. On the contrary, we found ostracods to be less sensitive to As than cladocerans; although this metal was not tested in the previous example and also in our case we did not use sediments but water with the toxic component. Such unexpected lower sensitivity of ostracods might be explained by mechanisms of environmental adaptative-self-protection e.g. a) tolerance to pollution with heavy metals related to the cells in the lamella externa, involved in apolysis and ecdysis process, b) excretion type through the hepatopancreas as detoxificant organ for crustaceans or c) living habits, ostracods are bentonic detritivores, while cladocerans are filter feeders and phytophagous zooplankton, and mosquitoes larvaes are zooplanktonic filter feeders. 
Citation: López-Gutiérrez, et al. Inter- and Intraspecific Variability in Invertebrate Acute Toxicity Response to Arsenic and Fluoride Exposure. (2018) J Environ Health Sci 4(1): 1-10.

Table 1: Results of the 48-h acute toxicity tests for As and F exposure ( $\mu$ gml-1) using six invertebrate groups.

\begin{tabular}{|c|c|c|c|c|c|c|c|}
\hline \multirow[t]{3}{*}{ Toxic } & Lethal toxicity & Brachionus & Culex sp. & Daphnia & Daphnia & Daphnia cf. & Heterocypris \\
\hline & indicators & patulus & & magna & magna & prolata & incongruens \\
\hline & Age & $72 \mathrm{~h}$ & Larvae $6.4+0.72 \mathrm{~mm}$ & $24 \mathrm{~h}$ & $5 \mathrm{~d}$ & $21 \mathrm{~d}$ & $48 \mathrm{~h}$ \\
\hline \multirow[t]{6}{*}{ As } & $\mathrm{LC}_{50}$ to $48 \mathrm{~h}$ & 0.737 & 5.837 & 0.549 & 0.906 & 0.423 & 1.143 \\
\hline & $95 \%$ C. L. of the $\mathrm{LC}_{50}$ & $0.25-2.25$ & $3.8-9.92$ & $0.4-0.878$ & $0.26-1.43$ & $0.38-0.89$ & $0.90-1.48$ \\
\hline & NOEC & 1.5 & 2.5 & 0.2 & 0.4 & 0.3 & 1.05 \\
\hline & LOEC & 1.77 & 3.5 & 0.4 & 0.8 & 0.8 & $>1.3$ \\
\hline & $\mathrm{r}^{2}$ Coefficient & 0.82 & 0.54 & 0.87 & 0.68 & 0.85 & 0.84 \\
\hline & Range & $0.17-2.4$ & $0.5-4.5$ & $0.2-1.8$ & $0.4-2.0$ & $0.8-1.7$ & $0.8-2.4$ \\
\hline \multirow[t]{7}{*}{$F$} & $\mathrm{LC}_{50}$ to $48 \mathrm{~h}$ & 234.297 & 396.058 & 206.381 & 593.078 & 502.773 & 44.073 \\
\hline & $95 \%$ C. L. of the $\mathrm{LC}_{50}$ & $129-262$ & $256-727$ & $192-264$ & $301-992$ & $447-825$ & $5.6-101$ \\
\hline & NOEC & $<125$ & $<300$ & $<100$ & $<525$ & $<755$ & 30 \\
\hline & LOEC & $>125$ & $>600$ & $>100$ & $>600$ & 1000 & 60 \\
\hline & $\mathrm{r}^{2}$ Coefficient & 0.97 & 0.97 & 0.68 & 0.87 & 0.96 & 0.91 \\
\hline & Range & $25-500$ & $300-1500$ & $100-1000$ & $100-600$ & $200-755$ & $15-200$ \\
\hline & Replicates & 6 & 3 & 3 & 3 & 3 & 9 \\
\hline
\end{tabular}

Binconcentration of As in the invertevr ates exposed 4 days $(N=2)$

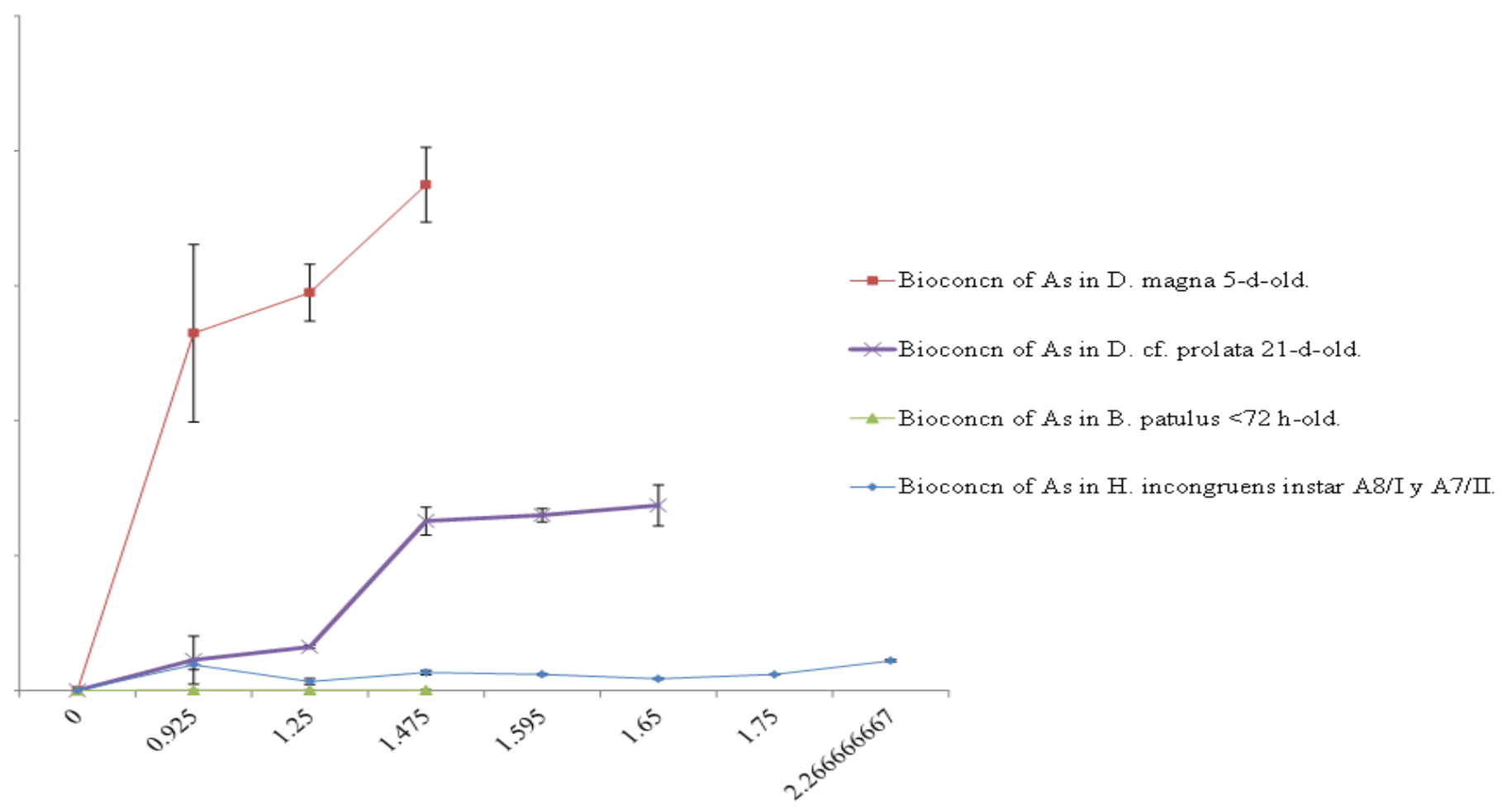

Exposure concentration of As in $\mathrm{ng}_{\mathrm{mg}} \mathrm{m}^{-1}$

Nuñez-Nogueira and Rainbow (2005) highlighted process of toxic-kinetics: absorption or adsorption, exposure times, distribution in tissues, metabolism of toxicants, and kind of excretion. They found in Penaeus indicus, that its antennal organs are excretory organs in which the hemolymph is filtered and subjected a selective resorptive process; it contained $10 \%$ of radio labeled zinc and lost in the next 10 days $74 \%$ when the crustacean molted. No information is known about the potential excretion of metals by ostracods.

Aguilar-Alberola and Mesquita-Joanes (2012) carried out acute toxicity tests on pre adult (A-1/VIII) and adult (A/IX) ostracod instars of Heterocypris bosniaca exposed to highly toxicogenic $\mathrm{Cd}^{+2}, \mathrm{~Pb}^{+2}$, cationic salt sodium dodecyl sulphate (SDS) and biocide Bacillus thuringiensis var. israelensis (Bti), the $\mathrm{LC}_{50}$ 's to 48 - $\mathrm{h}$ were $0.61,162.88,280.00$ and $298.75 \mu \mathrm{g} \mathrm{ml} \mathrm{I}^{-1}$ respectively. They found that these ostracods presented in general higher tolerance to toxic products compared to other organisms. Although we found $H$. incongruens to be less sensitive to arsenic, it was notably sensitive to sodium fluoride. The least sensitive organism we found with respect to As was Culex sp. Mogren et al. (2014) found certain tolerance of Culex species to arsenic exposures; the $\mathrm{LC}_{50}$ 's and $\mathrm{LC}_{90}$ 's of Culex quinquefasciatus exposed jointly to arsenic and Bti/Lysinibacillus sphaericus (Ls) were higher than in Cu- 
lex tarsalis, furthermore if reared in an arsenite [As (III)] higher toxicogenicity medium, it showed a significant reduction in their $\mathrm{LC}_{90 \text { s } \mathrm{s}+\mathrm{Bti}}$ values $\left(0.028 \mu \mathrm{gml}^{-1}\right)$ compared to the control $(0.046$ $\left.\mu \mathrm{gml}^{-1}\right)$, indicating a sublethal effect of Bti when combined with Ls.

\section{Fluoride}

For fluoride the sensitivity evaluated thorough 48-h $\mathrm{LC}_{50}$, in descending order was: 48-h-old $H$. incongruens $>$ 24h-old D. magna $>72 \mathrm{~h}$-old B. patulus $>$ Culex $\mathrm{sp} .=21$-d-old $D$. cf. prolata $=5$-d-old D. magna. Our $\mathrm{LC}_{50}$ values ranged from 44.073 to $593.78 \mu \mathrm{g} \mathrm{ml}^{-1}$. McClurg (1984) determined a $1118 \mu \mathrm{g}$ ml-1 96-h $\mathrm{LC}_{50}$ value for fluorides in seawater prawn Penaeus indicus. Fieser et al. (1986), using 24-h-old Daphnia magna neonates exposed 48-h to fluorides at temperatures of 15, 20 and $25^{\circ} \mathrm{C}$, found $\mathrm{LC}_{50^{\prime} \mathrm{s}}$ values of 304,251 and $200 \mu \mathrm{g} \mathrm{ml}^{-1}$ respectively. Differences in $\mathrm{LC}_{50 \text { 's }}$ values may be due to several biological factors like type of test organisms (Rubio-Franchini et al., 2008). Other factors mentioned by Weber (1993) are: a) the age of organisms, b) sensitivity, and c) tested abiotic conditions, quality of dilution water, e.g. cations reduced the toxicity of fluorides and arsenic (Philip 1990), d) the quality and amount of food provided (Schmit et al., 2007), e) the strains used as sentinel organism, f) conditions of the tests such as salinity, oxygen demand, and water quality (Puig and Sanz, 1987; Alvarado-Flores et al., 2012), and g) when the temperature is high, metabolic and/or toxicity are higher (Puig and Sanz, 1987). In the present work $B$. patulus and $H$. incongruens $\mathrm{LC}_{50^{\prime} \text { s }}$ were obtained at $25^{\circ} \mathrm{C}$, while for cladocerans and Culex sp. $\mathrm{LC}_{50^{\prime} \mathrm{s}}$ were obtained at $20^{\circ} \mathrm{C}$.

In the case of fluoride bioconcentration factors the descending order was: 5-d-old D. magna $<21$-d-old D. cf. prolata in glass jar $<21$-d-old $D$. cf. prolata in polyurethane jar $<H$. incongruens $<B$. patulus (Figure 2). Bioconcentration factors ranged from $30,993.8$ for 5-d-old D. magna to 0.76 for $B$. patulus (Figure 2). This huge range of bioconcentration might be due to the differences in strategies of bioaccumulation between ostracods and cladocerans (greater accumulators) vs rotifers whose cuticle might be highly impermeable to fluorides when compared to ostracods and cladocerans. Moulting might be a strategy that later allow cladocerans and ostracods to get rid of the fluorides thus initially accumulated. This variation in bioaccumulation factors influence the NOEC values whose ranges for fluorides are 30 to $<755 \mathrm{mg}$, and the LOEC values: $60-1000$ $\mu \mathrm{g} \mathrm{ml}^{-1}$ (Table 1). Rainbow \& White (1989), studying comparative strategies of bioaccumulation by three crustaceans: lobster shrimp Palaemonetes elegans, amphipod Echinogammarus sp., and barnacle Elminius pirloti modestus (whose dry weights were $0.15 \mathrm{~g}, 0.005 \mathrm{~g}$ and $0.001 \mathrm{~g}$ respectively), exposed to 10,100 and $1000 \mu \mathrm{g} \mathrm{ml}^{-1}$ of $\mathrm{Cd}$, under identical physic-chemical conditions, in artificial seawater $\left(33 \mathrm{ppt}, 10^{\circ} \mathrm{C}\right)$ for 28 days, showed different intake rates in order: barnacle $>$ amphipod $>$ decapod. According to Rainbow and White (1989), the impermeable nature of the cuticle (exoskeleton) of a decapod crustacean is a strategy of self-protection and pre-adaptation to heavy metal regulation to other toxicants. Indeed, in experiments on P. elegans, this decapod lost between 15 and $20 \%$ of the accumulated body burden of labeled $\mathrm{Zn}$ when moulting, although the unshed exoskeleton contained between 47 and $78 \%$ of this burden; thus the crustacean also reabsorbs $\mathrm{Zn}$ from the exoskeleton prior to moulting, the question would be: where is the rest 53 and $22 \% \mathrm{Zn}$ ?, is it in liquid environment where crustaceans were intoxicated, in exoskeleton, or in their body? Perhaps the answer comes from Turpen and Angell (1971) that found evidence for H. incongruens that in its moulting processes they did not absorb $\mathrm{Ca}^{45}$ from the old exosqueleton, but they took it from surrounding environment. Our results agree with these findings because juvenile instars of $H$. incongruens A- 8 and A-7, $<24$ and 48 hours old respectively, had higher burden body of $\mathrm{Cd}$ and $\mathrm{Pb}$ inside of moults than in whole body. Once they are intoxicated, their mechanisms of adaptive self-protection through moulting act to avoid death.

\section{Biocancentration of Fluoride in zooplancktants exposed 4 days $(\mathrm{n}=2)$}

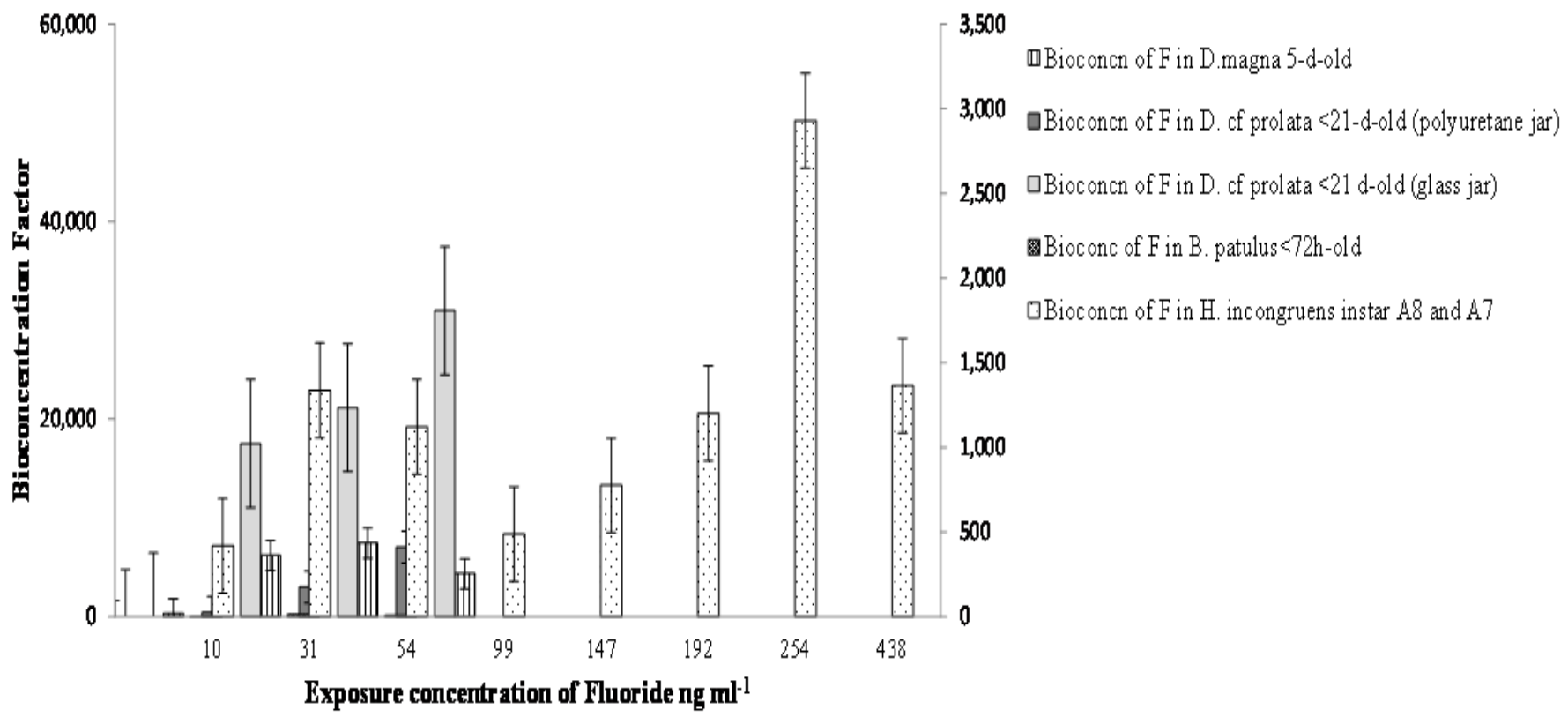


Citation: López-Gutiérrez, et al. Inter- and Intraspecific Variability in Invertebrate Acute Toxicity Response to Arsenic and Fluoride Exposure. (2018) J Environ Health Sci 4(1): 1-10.

According to the ANZECC (Australian and New Zealand Environment and Conservation Council in 1992), the parameters for the maximum concentration of heavy metals should not exceed 10-fold the lowest $\mathrm{LC}_{50}$. Brooks et al. (1995), who measured acute toxicity tests with heavy metals using as a test organism the common Australian ostracod Diacypris compacta, calculated $\mathrm{LC}_{50}$ to $96-\mathrm{h}$ for $\mathrm{Cu}, \mathrm{Zn}, \mathrm{Pb}$ and $\mathrm{Cd}$, which resulted to be $0.8,2.1,3.1$ and $4.3 \mu \mathrm{g} \mathrm{ml}^{-1}$, respectively and for 8 days, the $\mathrm{LC}_{50}$ were $0.4,0.7,2.2$ and $1.1 \mu \mathrm{g} \mathrm{ml}^{-1}$. According to the criteria of ANZECC (1992) the maximum acceptable concentrations in the Coorong area should be 4, 5, 22 and $9 \mu \mathrm{g} \mathrm{ml}^{-1}$ respectively, although higher $\mathrm{Cu}$ and $\mathrm{Zn}$ concentrations have been reported for the area of study in Australia being a significant danger to the aquatic biota. For our study the lowest $\mathrm{LC}_{50}$ values to 48 -h-post exposure with As were $0.457 \mu \mathrm{g} \mathrm{ml}^{-1}$ in native $D$. cf. prolata 21-d-old, while for $\mathrm{NaF}$, it was $48.07 \mu \mathrm{g} \mathrm{ml}^{-1}$ in native ostracods $H$. incongruens $<48$-h-old. Considering the criteria of ANZECC, the limit value would be 4.57 and $480.7 \mu \mathrm{g} \mathrm{ml}^{-1}$, respectively.

Pastorinho et al. (2009) warned about the risks of evaluating the toxic effects on adults only, or using only one species, or toxicologycally resistant species. In the case of this work, the use of several test organisms suggests that all species might be consider good model tests organisms for As except $H$. incongruens. However, some species bioaccumulated As, other like the rotifer $B$. patulus did not accumulated neither As nor NaF; and its sensitivity for both toxicants were found in the middle of both toxicants among the six groups studied. In contrast, $D$. cf. prolata accumulated more fluorine and was also (together with 5-d-old D. magna) the most tolerant to fluorine. For As, 5-d-old D. magna was the biggest accumulator but its sensivity is similar to all other species (except for $H$. incongruens). Interestingly, $H$. incongruens juvenile instars were the most sensitive species to NaF exposure. These results point out to the need of consider several invertebrate species as model organisms for environmental protection of particular ecosystems, or that some freshwater species have to the potential to be used as fluorine bioaccumulators in remediation processes.

\section{References}

- Aguilar-Alberola, J.A., Mesquita-Joanes, F. Acute Toxicity Tests with Cadmium, Lead, Sodium Dodecyl Sulfate, and Bacillus thuringiensis on a Temporary Pond Ostracod. (2012) Internat Rev Hydrobiol 97(4): 375-388.

Crossref|Others

- Alvarado-Flores, J., Silva-Briano, M., Rico-Martínez, R., et al. Bioconcentration and localization of lead in the freshwater rotifer Brachionus calyciflorus Pallas 1677 (Rotifera: Monogononta). (2012) Aquat Toxicol 109: 127-132.

Pubmed |Crossref | Others

- Ambasht, N.K., Ambasht, R.S. Modern trends in applied aquatic ecology. (2003) Kluwer Academia Plenum Publishers U.S.A 1st ed: 43-49.

Others

- ANZECC (Australian and New Zealand Environment and Conservation Council). Australian water quality guidelines for fresh and marine waters. (1992) Canberra, 202 pp.

- APHA Standard methods for the examination of water and wastewater, American public health association (2005) (21st ed) Others

- American Public Health Association, American Water works Association and Water Environment Federation.

- ASTDR, Agency for Toxic Substances and Disease Registry. (2007). Toxicological Profile for Arsenic U.S. Department of Health and Human Services Public Health Service Agency for Toxic Substances and Disease Registry August 2007.

Others

- Bailey, K., Chilton, J., Dahi, E., et al. Fluoride in Drinking-water. (2006) World Health Organization (WHO) titles with IWA Publishing 8-35.

Crossref|Others

- Barka, S., Pavillon, J.F., Amiard, J.C. Influence of different essential and non-essential metals on MTLP levels in the Copepod Tigriopus brevicornis. (2001) Compar Biochem Physiol 128(4): 479-493.

Pubmed | Crossref $\mid$ Others

- Brooks, A., White, R.M., Paton, D.C. Effects of heavy metals on the survival of Diacypris compacta (Herbst) (OSTRACODA) from the Coorong, South Australia. (1995) Internat J Salt Lake Res 4(2): 133-163.

Crossref $\mid$ Others

- Camargo, J.A. Fluoride toxicity to aquatic organisms: a review. (2002) Chemosphere 50(3): 251-264.

Pubmed | Crossref $\mid$ Others

- Canivet, V., Chambon, P., Gibert, J. Toxicity and bioaccumulation of arsenic and chromium in epigean and hypogean freshwater macroinvertebrates. (2001) Arch Environ Contam Toxicol 40: 345-354.

Pubmed | Crossref | Others

- Chial, B., Persoone, G. Cyst-Based Toxicity Tests XV - Application of Ostracod Solid-Phase Microbiotest for Toxicity Monitoring of Contaminated Soils. (2003) Environ Toxicol 18(5): 347-352.

Pubmed | Crossref | Others

- Fieser, A.H., Sykora, J.L., Kostalos, M.S., et al. Effect of fluorides on survival and reproduction of Daphnia magna. (1986) J Water Pollut Control Fed 58(1): 82-86.

Crossref $\mid$ Others

- Forget, J.J.F., Pavillon, M., Menasria, M.R., et al. Mortality and $\mathrm{LC}_{50}$ values for several stages of the marine copepod Tigriopus brevicornis (Möller) exposed to the metals arsenic and cadmium and the pesticides atrazine, carbofuran, dichlorvos and malathion. (1998) Ecotoxicol Environ Saf 40(3): 239-244. Pubmed | Crossref $\mid$ Others

- Havel, J.E., Talbott, B.L. Life history characteristics of the freswater ostracod Cyprinotus incongruens and their application to toxicity testing. (1995) Ecotoxicology 4(3): 206-218.

Others

- Hevert, C.F. A Guide to Tropical freshwater zooplankton identification, ecology and impact on fisheries. (2002) Backhuys publishers Leiden. The Netherlands. Pp. 189-223.

Others

- Jaramillo J F; Rincón S A R \& Rico, M. R. 2009. Toxicología 
ambiental. Universidad Autónoma de Aguascalientes, México. pp.39.

Others

- Koste, W. Rotatoria Die Rädertsere Mitteleuropas, Ein Bestimmungswerk, begründet von Max Voigt Uberdnung Monogononta 2. Auflage neuvarbeitet von Walter Koste Quaquenbrük, Tafel band (1978) 1-10. $234 \mathrm{pp}$.

- McClurg, T.P. Effects of fluoride, cadmium and mercury on the estuarine prawn Penaeus indicus. (1984) Water SA 10(1): 40-45. Others

- Meisch, C. Freshwater Ostracoda of Western and Central Europe. (2000) Spektrum, Gustav Fischer, 522.

Others

- Mitchell, E., Frisbie, S., Sarkar, B. Exposure to multiple metals from groundwater - a global crisis: geology, climate change, health effects, testing, and mitigation. (2007) Metallomics 3(9): 874-908.

\section{Pubmed | Crossref | Others}

- Mogren, C.L., Walton, E.W., Trumble, J.T. Tolerance to individual and joint effects of arsenic and Bacillus thuringiensis sub$\mathrm{sp}$. israelensis or Lysinibacillus sphaericus in Culex mosquitoes. (2014) Insect Science 21(24): 477-485.

Pubmed | Crossref | Others

- Nichols, H.W. Growth media - freshwater. In: Stein J.R. (Ed.). Handbook of Phycological Methods. (1973) Cambridge University Press, New York 13-14.

Others

- Nuñez-Nogueira, G., Rainbow, P.S. Kinetics of zinc uptake from solution, accumulation and excretion by the decapod crustacean Penaeus indicus. (2005) Marine Biol 147(1): 93-103.

Others

- Oleszczuk, P. The Evaluation of Sewage Sludge and Compost Toxicity to Heterocypris incongruens in Relation to Inorganic and Organic Contaminants Content. (2007) Environ Toxicol 22(6): 587-596.

Pubmed | Crossref | Others

- Paquin, P.R., Farley, K., Santore, R.C., et al. Metals in Aquatic Systems: a Review of Exposure. (2003) Bioaccumulation, and Toxicity Models. SETAC Press, Pensacola, Florida, p. 140. Others

- Pastorinho, R., Trevor, T., Soares, A.M. Amphipod susceptibility to metals: cautionary tales. (2009) Chemosphere 75(11): 1423-1428.

Pubmed | Crossref | Others

- Philips J.H. Arsenic in aquatic organisms: a review, emphasizing chemical speciation . (1990) Aquat Toxicol 16(3): 151-186. Crossref | Others

- Puig, J.V., Sanz, A. Consumo de oxígeno de Palaemonetes zariquieyi Sollaud, (CRUSTACEA: DECAPODA: PALAEMONIDAE), efectos de la temperatura y la salinidad.

(1939) Inv Pesq 51(1): 515-524.

Others

- Rainbow, P.S., White, S.L. Comparative strategies of heavy metal accumulation by crustaceans: zinc, copper and cadmium in a decapod, an amphipod and a barnacle. (1989) Hydrobiologia 174(3): 245-262.

Others

- Rubio-Franchini, I., Mejía-Saavedra, J.J., Rico-Martínez, R. Determination of Lead in Samples of Zooplankton, Water, and Sediments in a Mexican Reservoir: Evidence for Lead Biomagnification in Lower/Intermediate Trophic Levels? (2008) Environ Toxicol 23(4): 459-465.

Pubmed $\mid$ Crossref $\mid$ Others

- Schmit, O., Rossetti, G., Vandekerkhove, J., et al. Food selection in Eucypris virens (Crustacea: Ostracoda) under experimental conditions. (2007) Hydrobiologia 585(1): 135-140. Others

- Secretaría de Salud y Asistencia. NOM-117-SSA1-1994. Norma Oficicial Mexicana NOM-117-SSA1-1994, bienes y servicios. Método de prueba para la determinación de cadmio, arsénico, plomo, estaño, cobre, fierro, zinc y mercurio en alimentos, agua potable y agua purificada por espectrometría de absorción atómica (1994).

Others

- Taylor, E.W., Butler, P. J., Al-Wassia, A. Some responses of the shore crab, Carcinus maenas (L.), to progressive hypoxia at different acclimation temperatures and salinities. (1977) J Comp Physiol 122(3): 391-402.

Crossref| Others

- Turpen, J.B., Angell, R.W. Aspects of molting and calcification in the Ostracod Heterocypris. (1971) The Biological Bulletin 140(2): 331-338.

Crossref| Others

- Weber, C.I. Methods for measuring the acute toxicity of effluents and receiving waters to freshwater and marine organisms. Fourth edition. EPA/600/4-90/027F. Environmental Monitoring Systems Laboratory. Cincinnati office of research and development U.S. (1993) Env Protection Ag Others

- World Health Organization. Guidelines for Drinking-Water Quality-Incorporating First Addendum to Third Edition - Volume 1: Recommendations World Health Organization (2006) $595 \mathrm{pp}$.

Others 